\title{
Cytology of Vicia Species. 5. Nuclear Chromatin Structure, Karyomorphological Analysis and DNA Content in Newly Discovered Relatives of Vicia faba L.: Vicia kalakhensis Khattab, Maxted et Bisby and Vicia eristalioides Maxted
}

\author{
Roberto Cremonini, ${ }^{1, *}$, Doria Miotto ${ }^{1}$, Mary Api Ngu ${ }^{2}$, Donato Tota ${ }^{2}$, \\ Domenico Pignone ${ }^{2}$, Sebastiano Blangiforti ${ }^{3}$ \\ and Gianfranco Venora ${ }^{3}$ \\ ${ }^{1}$ Dipartimento di Scienze Botaniche dell'Università di Pisa, Italy \\ ${ }^{2} \mathrm{CNR}$, Istituto del Germoplasma, Bari, Italy \\ ${ }^{3}$ Stazione sperimentale di Granicoltura per la Sicilia, Caltagirone, Italy \\ Accepted July 15, 1998
}

\begin{abstract}
Summary Three species of the Vicia narbonensis complex, namely $V$. narbonensis L., V. kalakensis Khattab, Maxted et Bisby and V. eristalioides Maxted were analysed for different karyobiological features; the nuclear DNA content and DNA absorption curves were determined, karyomorphometric data were generated using an automated image analysis system and the distribution and staining properties of heterochromatin in metaphase chromosomes, were assessed.

Feulgen absorptions at different thresholds of optical density provided evidence of organisation of the chromatin interphase nuclei and allowed an evaluation of the heterochromatin amount as determined with a cytophotometrical approach. The precise chromosomal measurements were utilised for computing karyomorphological indices.

Key words Chromosome banding, Fluorochromes, Heterochromatin, Interphase nucleus structure, Vicia species, Image analysis.
\end{abstract}

The genus Vicia comprises aproximately 160 species (Alkin et al. 1986) widely distributed throughout the temperate zone of both hemispheres and many of them, mainly of Eurasian origin, are cultivated for food and fodder. The majority shows a basic number of $x=5,6$ or 7 and only eight species are polyploids ( $2 n=4 x=24$ or 28 , Raina and Ogihara 1985).

The speciation in this genus is accompanied by both chromosome size variation and large scale variation in nuclear DNA content, as well as variation in the frequency of repetitive and non repetitive DNA sequences (Cremonini 1990 and references therein). Lately Maxted (1991a) revised the classifications of Chooi (1971), Kupicha (1976) and Hanelt and Mettin (1989). In this classification the genus Vicia is subdivided in two sub-genera, namely Vicia and Vicilla, with 17 and 9 sections respectively, ten rare taxa from both subgenera and new species (Maxted 1988, Khattab et al. 1988) were included. In the classification of Maxted et al. (1991a) the section Faba is composed of three distinct units: two are monospecific: $V . f a b a$ in the former and $V$. bithynica in the latter, while the third is larger and contains the seven species referred to as the Narbonensis complex.

In previous papers biochemical and cytophotometric data on Vicia species belonging to the Faba section have been reported (Cremonini et al. 1992, 1993, Frediani et al. 1992, Maggini et al. 1995). The karyological relationships among the species of this section had been analysed at both 
cytological and banding levels (Schafer 1973, Perrino and Pignone 1981). The conclusion of the reported studies was that for karyobiological parameters the species of the section Faba do not form an homogeneous aggregate: some species show a great resemblance to $V$. narbonensis, and therefore they were generally treated together as the $V$. narbonensis group.

Recently two new species (Vicia kalakhensis Khattab, Maxted et Bisby and Vicia eristalioides Maxted) were discovered, identified and included for their morphological characters in the V. narbonensis group by Maxted et al. (1991a). Therefore the nuclear DNA content, the chromatin organisation, the chromosomal indices and the distribution and staining properties of chromosomal heterochromatin were analysed.

\section{Materials and methods}

Seeds of Vicia khalakhensis and Vicia eristalioides, kindly provided by Dr. N. Maxted and $V$. narbonensis belonging to the collection held at the Istituto del Germoplasma, Bari, were used.

For cytophotometric analysis seeds of the three species were soaked in running tap water overnight and germinated in Petri dishes at $22^{\circ} \mathrm{C}$ in darkness for two days and transferred in sterilised water vessels until secondary roots were about $1 \mathrm{~cm}$ long. Root tips were fixed in ethanol-acetic acid $(3: 1, \mathrm{v} / \mathrm{v})$. Squashes were made under a coverslip in a drop of $45 \%$ acetic acid after treatment with a $5 \%$ aqueous solution of pectinase (Sigma) for $1 \mathrm{hr}$ at $37^{\circ} \mathrm{C}$ with the áddition of 0.001 M EDTA in order to annul the activity of DNase (Berlyn et al. 1979). The coverslips were removed by the dry-ice method, and the squashes were hydrolysed in $5 \mathrm{~N} \mathrm{HCl}$ at room temperature for $30 \mathrm{~min}$ and stained by Feulgen reagent. After staining, the slides were subjected to three washes, each of 10 min intervals, in $\mathrm{SO}_{2}$ water prior to dehydration and mounting in DPX (Fluka). Squashes of the root tips of Vicia narbonensis were concurrently stained for each group of slides and used as an internal standard.

Absorptions measured in $V$. narbonensis preparations were also used to convert relative Feulgen arbitrary units into picograms of DNA. Feulgen DNA absorptions in individual cell nuclei, in the postsynthetic condition $\left(\mathrm{G}_{2}\right)$, were measured at the wavelength of $550 \mathrm{~nm}$, using a Leitz MPV3 integrating microdensitometer equipped with an HP computer. With the same instrument and at the same wavelength, the Feulgen DNA absorptions of chromatin fractions with different condensation levels were determined by measurements of one and the same nucleus, after selecting different thresholds of optical density according to the method of Di Terlizzi et al. (1993). The instrument reads all parts of the nucleus where the optical density is greater than the preselected limit, regarding those below this limit as a clear field. The optical density threshold values were mathematically elaborated in order to obtain the exact position of the inflexion point in the curves and it was possible to discriminate between two areas of integral calculation using Simpson's rule. The residual Feulgen absorption at the inflexion point represents the cytophotometrically determined heterochromatin (Cremonini et al. 1993).

The integral calculation was carried out on the best-fit curves obtained from three curves of optical density for each sample. In order to assess whether some chromatin fractions contributed to cytophotometric differences among the species, measurements were taken on interphase nuclei at different thresholds of optical density. Interphase nuclei, with Feulgen absorption values of $4 \mathrm{C}$ content and the same surface, were chosen for each species.

Karyotype morphometry was made by an automated image analysis system IBAS 2000 by Kontron-Zeiss. Slides were prepared and analysed according to Venora et al. (1991). The classification of Stebbins (1971), the TF\% index (Huziwara 1962) and the Rec and SYi indices (Greilhuber and Speta 1976) were used to perform the analysis. The classification of Stebbins (1971) is based on the relative frequency of chromosomes with a long arm ratio greater than 2 and on the ratio between the lengths of the longest and the shortest chromosome in the complement. The TF\% index is 
Table 1. Chromosome number, Feulgen absorption (a.u., mean \pm S.E.), surface of interphase nuclei $\left(\mu \mathrm{m}^{2}\right.$, mean \pm S.E.), nuclear DNA content (pg, mean \pm S.E.) in Vicia samples. Nuclear DNA content of $V$. narbonensis is used as internal standard. Each Feulgen absorption value is the mean of 100 determinations carried out in root meristems: twenty prophases for each of five seedlings

\begin{tabular}{lcccc}
\hline \hline Species & $\begin{array}{c}\text { Chromosome } \\
\text { number }\end{array}$ & $\begin{array}{c}\text { Feulgen } \\
\text { absorption }\end{array}$ & $\begin{array}{c}\text { Interphase nuclei } \\
\text { surface }\end{array}$ & DNA amount \\
\hline V. kalakhensis & 14 & $2580.9 \pm 25.9$ & $2387.5 \pm 98.3$ & $42.22 \pm 0.4$ \\
V. eristalioides & 14 & $2351.8 \pm 32.3$ & $2949.8 \pm 51.6$ & $38.58 \pm 0.5$ \\
V. narbonensis & 14 & $1770.8 \pm 21.1$ & $2399.3 \pm 53.8$ & $29.10^{*}$ \\
\hline
\end{tabular}

* Frediani et al. 1992. Biol. Plant 34: 335-344.

expressed by the ratio between the sum of the lengths of the short arms of individual chromosomes and the total length of the complement. The Rec index expresses the average of the ratios between the length of each chromosome and that of the longest one. The SYi value indicates the ratio between the average length of the short arms and the average length of the long arms. Cluster analysis was applied for grouping chromosome pairs (Scott and Knott 1974). The Levan et al. (1964) nomenclature was followed excluding the satellite length in computing the arm ratio.

For chromosome banding, actively growing roots of the three species were excised and treated with ice-cold distilled water for 18$24 \mathrm{hr}$ in order to accumulate metaphases. The roots were then fixed for $24 \mathrm{hr}$ in ethanolacetic acid $(3: 1, \mathrm{v} / \mathrm{v})$. Root tip meristems were

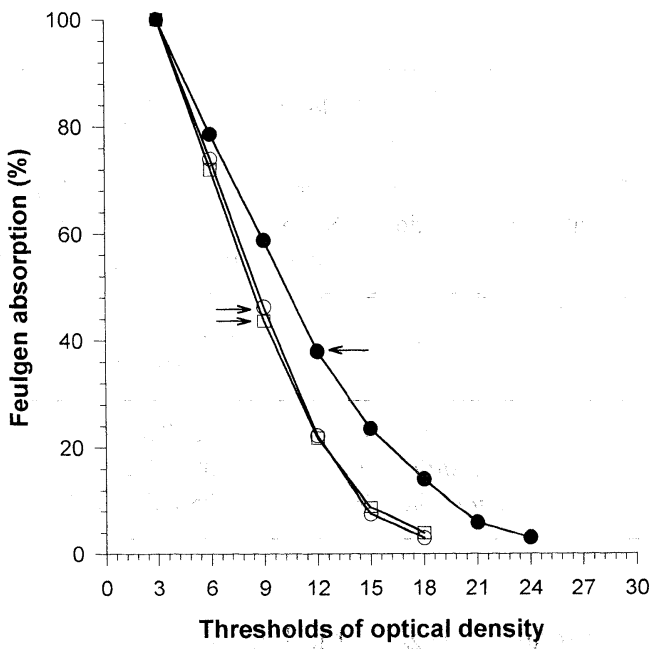

Fig. 1. Percentage of Feulgen absorption at different thresholds of optical density of $4 C_{\text {s }}$ interphase nuclei in Vicia narbonensis $(\bigcirc)$, Vicia kalakhensis $(-)$ and Vicia eristalioides $(\square)$, the arrows indicate the position of inflexion points: squashed under coverslips in a drop of $45 \%$ acetic acid, coverslips were removed by the dry-ice method and slides were dried overnight. Staining with bis-benzimide derivative Hoechst H33258 followed Perrino and Pignone (1981), C-banding (BSG) was performed according to Giraldez et al. (1979). Banded karyotypes were constructed taking into account chromosomal indices and band position. Karyotypes of the different species were assembled in order to maximize the similarities among the species.

\section{Results}

\section{Cytophotometry}

The mean Feulgen absorption and the mean surface of early prophases, the chromosome number and the nuclear DNA content in each of the analysed species are listed in Table 1. From the analysis of hydrolysis curve, the optimal time for Feulgen reaction, was 30 min with $5 \mathrm{~N} \mathrm{HCl}$ at room temperature. The DNA content differs from one species to another as evidenced by statistical analysis: from 42.22 in $V$. kalakhensis to 29.10 in $V$. narbonensis (pg/4C nucleus). A linear relationship between total length of haploid complement and nuclear DNA content was found $(r=0.94)$ and the results of the analysis at different thresholds of optical density are summarized in Fig. 1 and in Table 2. At optical density thresholds 21 , the Feulgen absorption of $V$. eristalioides and $V$. narbonen- 
Table 2. Percentages of Feulgen absorption (mean \pm S.E.) at different thresholds of optical density of $4 \mathrm{C}$ interphase nuclei in the root meristems of five seedlings for each sample ( 20 nuclei for each seedling were measured)

\begin{tabular}{cccc}
\hline \hline \multirow{2}{*}{$\begin{array}{c}\text { Thresholds of } \\
\text { optical density }\end{array}$} & \% Feulgen absorption ( \pm S.E.) & \\
\cline { 2 - 4 } & V. kalakhensis & V. eristalioides & Varbonensis \\
\hline 3 & 100 & 100 & 100 \\
6 & $78.55 \pm 0.73$ & $73.97 \pm 0.88$ & $72.01 \pm 1.11$ \\
9 & $58.79 \pm 0.93$ & $46.27 \pm 1.29^{*}$ & $43.70 \pm 1.40^{*}$ \\
12 & $37.97 \pm 1.02^{*}$ & $22.18 \pm 1.26$ & $21.80 \pm 1.16$ \\
15 & $23.55 \pm 1.09$ & $7.41 \pm 0.83$ & $3.81 \pm 0.86 \pm 0.56$ \\
18 & $14.06 \pm 1.53$ & $2.96 \pm 0.55$ & - \\
21 & $5.80 \pm 0.58$ & - & - \\
24 & $3.03 \pm 0.28$ & - & - \\
\hline
\end{tabular}

* Indicates the inflexion point position.

Table 3. Prophase nuclei surface $\left(\mu \mathrm{m}^{2}\right.$, mean \pm S.E. $)$, estimation threshold values, areas $\left(\mathrm{S}_{1}\right.$ and $\mathrm{S}_{2}$, arbitrary units) from integral calculation by Simpson's rule and ratio $\mathrm{S}_{2} / \mathrm{S}_{1}$. The integral calculation was carried out on the best fit curve obtained from three curves of optical density for each for each species

\begin{tabular}{lccccc}
\hline \hline Species & $\begin{array}{c}\text { Mean surfaces of } \\
\text { prophase nuclei }\end{array}$ & $\begin{array}{c}\text { Threshold } \\
\text { values }=0\end{array}$ & $\mathrm{~S}_{1}$ & $\mathrm{~S}_{2}$ & $\mathrm{~S}_{2} / \mathrm{S}_{1}$ \\
\hline V. kalakhensis & $2508.3 \pm 57.4$ & 27 & 645.23 & 94.8 & 0.144 \\
V. eristalioides & $3082.3 \pm 43.5$ & 21 & 544.93 & 63.1 & 0.115 \\
V. narbonensis & $2561.8 \pm 46.7$ & 21 & 545.42 & 66.1 & 0.121 \\
\hline
\end{tabular}

sis is reduced to zero, the Feulgen absorption of $V$. kalakhensis is $5.8 \%$ and is reduced to zero at the higher threshold of optical density, i.e. 27.

By mathematical elaboration based on Simpson's rule it is possible the determination of the inflexion point of the three curves optimised from the experimental data. This point enables the identification of two areas in each curve $\left(\mathrm{S}_{1}\right.$ and $\left.\mathrm{S}_{2}\right)$ and the value of the second area is found to be similar when comparing the two species $V$. eristalioides and $V$. narbonensis and higher in $V$. kalakhensis (Table 3). A similar pattern is evidenced by the ratio $\left(\mathrm{S}_{2} / \mathrm{S}_{1}\right)$ between the areas. Moreover, when the ratio of $\mathrm{S}_{1}$ over $\left(\mathrm{S}_{1}+\mathrm{S}_{2}\right)$ is considered, a similar observation is done. The ratio is in fact the entity of the denser chromatin in relation to the total chromatin as read by the instrument and therefore it describes the cytophotometrically determined heterochromatin in interphase nuclei.

\section{Karyotypes}

All karyological data for the three species are reported in Table 4 and karyograms and chromosome banding patterns are reported in Fig. 2 as well as the chromosomal distribution of heterochromatin is reported.

Vicia eristalioides: the individual chromosome lengths ranged from 3.98 to $5.59 \mu \mathrm{m}$, with a total length of the haploid complement equal to $33.38 \mu \mathrm{m}$. One satellite was located on the short arm of the second chromosome. Based on arm-ratios, the seven chromosome pairs could be divided into three groups (same letter according to Cluster analysis, Table 4). Three chromosome pairs possessed metacentric centromeres and four had submetacentric centromeres.

Vicia kalakensis: chromosome length varied from 5.0 to $6.93 \mu \mathrm{m}$; the total chromosome length of the haploid set was $42.28 \mu \mathrm{m}$. The second pair of chromosomes carried a $2.34 \mu \mathrm{m}$ long satellite on the short arm. Three chromosomes had the centromere located in metacentric position, three in 
Table 4. Chromosome morphometric values (mean \pm S.E.) of Vicia samples

\begin{tabular}{|c|c|c|c|c|c|c|c|}
\hline $\begin{array}{c}\text { Chromosome } \\
\text { No. }\end{array}$ & $\begin{array}{l}\text { Relative } \\
\text { length }(\%)\end{array}$ & $\begin{array}{l}\text { Length } \\
(\mu \mathrm{m})\end{array}$ & $\begin{array}{l}\text { Long arm } \\
\qquad(\mu \mathrm{m})\end{array}$ & $\begin{array}{l}\text { Short arm } \\
\qquad(\mu \mathrm{m})\end{array}$ & $\begin{array}{l}\text { Satellite } \\
\qquad(\mu \mathrm{m})\end{array}$ & $\begin{array}{l}\text { Arm ratio } \\
\text { long/short }\end{array}$ & $\begin{array}{c}\text { Chromosome } \\
\text { type }\end{array}$ \\
\hline \multicolumn{8}{|l|}{ V. eristalioides } \\
\hline 1 & 16.72 & $5.58 \mathrm{aA}$ & $3.27 \pm 0.03$ & $2.31 \pm 0.13$ & \multirow{7}{*}{$1.98 \pm 0.12$} & $1.41 \mathrm{dC}$ & \multirow{7}{*}{$\begin{array}{c}\text { metacentric } \\
\text { submetacentric } \\
\text { metacentric } \\
\text { metacentric } \\
\text { submetacentric } \\
\text { submetacentric } \\
\text { submetacentric }\end{array}$} \\
\hline 2 & 15.99 & $5.34 \mathrm{bB}$ & $2.30 \pm 0.06$ & $1.06 \pm 0.07$ & & $2.16 \mathrm{aA}$ & \\
\hline 3 & 15.59 & $5.20 \mathrm{cC}$ & $3.16 \pm 0.11$ & $2.04 \pm 0.03$ & & $1.55 \mathrm{cC}$ & \\
\hline 4 & 14.38 & $4.80 \mathrm{dD}$ & $2.91 \pm 0.22$ & $1.89 \pm 0.19$ & & $1.54 \mathrm{cC}$ & \\
\hline 5 & 13.04 & $4.35 \mathrm{eE}$ & $2.98 \pm 0.16$ & $1.37 \pm 0.18$ & & $2.18 \mathrm{aA}$ & \\
\hline 6 & 12.36 & $4.13 \mathrm{fF}$ & $2.71 \pm 0.07$ & $1.42 \pm 0.05$ & & $1.92 \mathrm{bB}$ & \\
\hline 7 & 11.92 & $3.98 \mathrm{gG}$ & $2.70 \pm 0.01$ & $1.28 \pm 0.11$ & & $2.12 \mathrm{aA}$ & \\
\hline \multicolumn{8}{|l|}{ V. kalakhensis } \\
\hline 1 & 16.39 & $6.93 \mathrm{aA}$ & $4.07 \pm 0.04$ & $2.86 \pm 0.10$ & \multirow{7}{*}{$2.34 \pm 0.26$} & $1.43 \mathrm{eE}$ & \multirow{7}{*}{$\begin{array}{c}\text { metacentric } \\
\text { subtelocentric } \\
\text { metacentric } \\
\text { submetacentric } \\
\text { submetacentric } \\
\text { metacentric } \\
\text { submetacentric }\end{array}$} \\
\hline 2 & 15.52 & $6.56 \mathrm{bB}$ & $3.22 \pm 0.11$ & $1.00 \pm 0.15$ & & $3.21 \mathrm{aA}$ & \\
\hline 3 & 15.21 & $6.43 \mathrm{cB}$ & $3.85 \pm 0.15$ & $2.58 \pm 0.06$ & & $1.49 \mathrm{eE}$ & \\
\hline 4 & 14.78 & $6.25 \mathrm{dC}$ & $4.17 \pm 0.13$ & $2.08 \pm 0.09$ & & $2.00 \mathrm{bB}$ & \\
\hline 5 & 13.94 & $5.89 \mathrm{eD}$ & $3.79 \pm 0.03$ & $2.10 \pm 0.01$ & & $1.80 \mathrm{cC}$ & \\
\hline 6 & 12.35 & $5.22 \mathrm{fE}$ & $3.23 \pm 0.03$ & $1.99 \pm 0.14$ & & $1.62 \mathrm{dD}$ & \\
\hline 7 & 11.82 & $5.00 \mathrm{gF}$ & $3.36 \pm 0.18$ & $1.64 \pm 0.05$ & & $2.05 \mathrm{bB}$ & \\
\hline \multicolumn{8}{|l|}{ V. narbonensis } \\
\hline 1 & 16.46 & $4.47 \mathrm{aA}$ & $2.87 \pm 0.10$ & $1.60 \pm 0.13$ & & $1.79 \mathrm{dC}$ & \multirow{7}{*}{$\begin{array}{l}\text { submetacentric } \\
\text { metacentric } \\
\text { submetacentric } \\
\text { metacentric } \\
\text { submetacentric } \\
\text { submetacentric } \\
\text { submetacentric }\end{array}$} \\
\hline 2 & 15.46 & $4.20 \mathrm{bB}$ & $2.60 \pm 0.17$ & $1.60 \pm 0.05$ & & $1.62 \mathrm{eD}$ & \\
\hline 3 & 14.81 & $4.02 \mathrm{cC}$ & $2.65 \pm 0.05$ & $1.37 \pm 0.04$ & & $1.93 \mathrm{cB}$ & \\
\hline 4 & 14.21 & $3.85 \mathrm{dD}$ & $2.31 \pm 0.20$ & $1.54 \pm 0.09$ & & $1.50 \mathrm{fE}$ & \\
\hline 5 & 13.85 & $3.76 \mathrm{eD}$ & $2.42 \pm 0.04$ & $1.34 \pm 0.06$ & & $1.81 \mathrm{dC}$ & \\
\hline 6 & 13.11 & $3.56 \mathrm{fE}$ & $2.37 \pm 0.30$ & $1.19 \pm 0.03$ & & $1.99 \mathrm{bB}$ & \\
\hline 7 & 12.11 & $3.29 \mathrm{gF}$ & $1.53 \pm 0.06$ & $0.74 \pm 0.11$ & $1.02 \pm 0.01$ & $2.07 \mathrm{aA}$ & \\
\hline
\end{tabular}

Values followed by the same letter are not significantly different, according to the Cluster analysis of Scott and Knott (capital letters small letters $\mathrm{P}=0.05$ ).
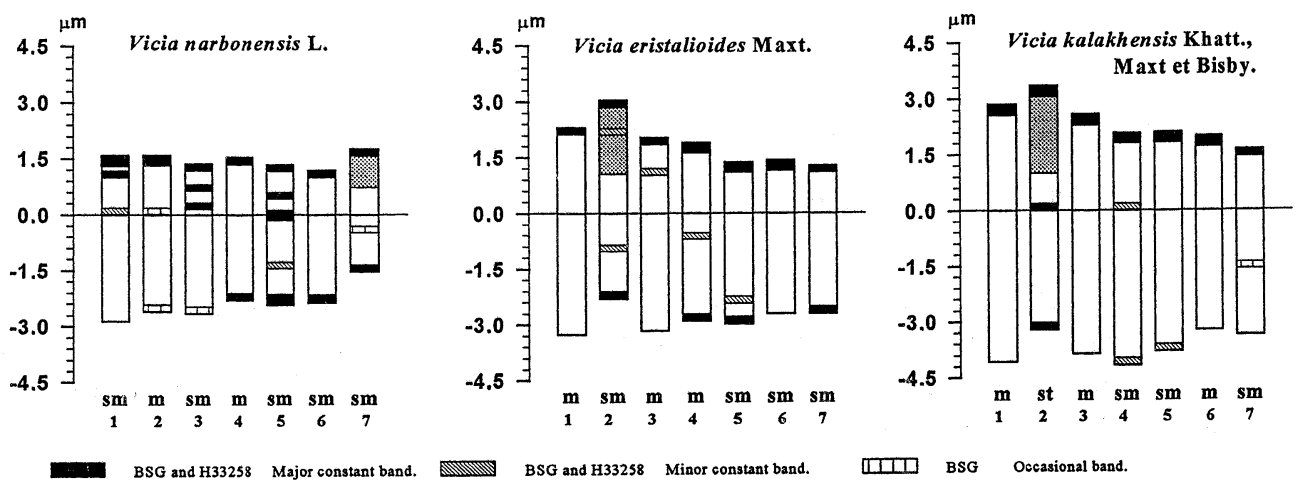

Fig. 2. Idiogrammatic representation of the haploid karyotype and bands localization on each species. $\mathrm{BSG}=\mathrm{C}$ banding.

submetacentric and one in subtelocentric position. According to arm-ratio the seven pairs were grouped in five clusters (Table 4).

Vicia narbonensis: the length of individual chromosomes ranged from 3.29 to $4.47 \mu \mathrm{m}$ and the length of the haploid complement was $27.14 \mu \mathrm{m}$. A $1.02 \mu \mathrm{m}$ long satellite was located on the short arm of the shortest chromosome pair. Five chromosome pairs possessed submetacentric centromeres and two metacentric centromeres and the seven chromosome pairs were grouped in five clusters according to the arm-ratio (Table 4).

As long as karyomorphological values are concerned, Vicia kalakhensis showed the lowest val- 
Table 5. Karyotype formulas, set lengths $(\mu \mathrm{m})$, indices and Stebbins categories in Vicia samples

\begin{tabular}{lccc}
\hline \hline & V. eristalioides & V. kalakhensis & V. narbonensis \\
\hline Karyotype formula & $\mathrm{sm}^{\mathrm{sc}}+3 \mathrm{~m}+3 \mathrm{sm}$ & $\mathrm{st}^{\mathrm{sc}}+3 \mathrm{~m}+3 \mathrm{sm}$ & $\mathrm{sm}^{\mathrm{sc}}+2 \mathrm{~m}+4 \mathrm{sm}$ \\
Total length of haploid set & $33.38 \pm 0.37$ & $42.28 \pm 0.10$ & $27.14 \pm 2.28$ \\
Rec Index & 83.02 & 85.02 & 84.60 \\
Sy Index & 56.76 & 55.52 & 56.05 \\
TF\% Index & 34.07 & 33.73 & 34.57 \\
Stebbin's categories & AII & AII & AII \\
\hline
\end{tabular}
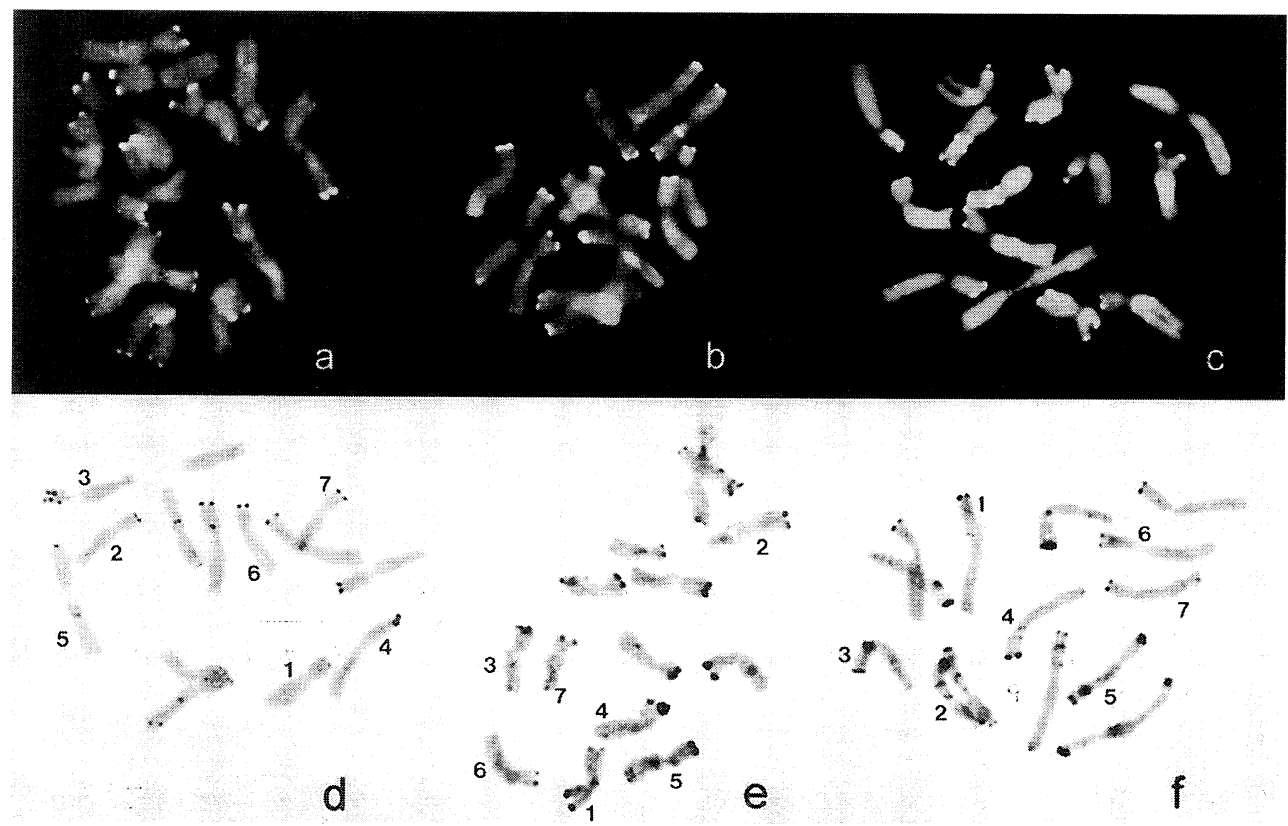

Fig. 3. Metaphase chromosomes of Vicia kalakhensis (a, d), Vicia eristalioides (b, e) and Vicia narbonensis (c,f) stained with H33258 (a-c) and C-banding (d-f). $\times 1200$. The numbers on C-banded chromosomes correspond with the numeration of the idiogrammatic representation.

ues of $\mathrm{Sy}_{\mathrm{i}}$ (55.52) and TF\% (33.73), the longest haploid complement, the longest satellite and the longest pair of chromosome (the first), on the contrary, Vicia narbonensis showed the shortest haploid complement. Karyotype formulas, the indices $\mathrm{Rec}, \mathrm{Sy}_{\mathrm{i}}$ and $\mathrm{TF} \%$ and the categories according to Stebbins (1971) are summarised in Table 5.

\section{Chromosome banding}

In the three species examined the heterochromatin had essentially telomeric distribution (Fig. 3). Large heterochromatic blocks were located mainly at the short arms telomeres, few blocks were seen at the long arms telomeres. Intercalary heterochromatin was not frequent and major intercalary blocks were seen at the satellited chromosomes in all species. Minor intercalary bands were often seen on the long arms, but these bands had generally an occasional nature. The ideograms reporting bands distribution were overlaid on those developed with image analysis, the composed ideograms are given in Fig. 2.

The general distribution of the C-bands was very similar in all species examined and major differences regarded the satellited chromosomes. The chromosomes of Vicia eristalioides and those of Vicia narbonensis appeared to have a larger proportion of heterochromatin than those of Vicia 
kalakensis. In fact, if the percentage of chromosomal heterochromatin is calculated according to the method of Venora et al. (1995) the three species show $8 \%, 8 \%$ and $6 \%$ respectively.

When $\mathrm{H} 33258$ staining was applied, the large constant heterochromatin blocks took up a bright fluorescence, the H33258 banding patterns were very constant and species-specific and no intercalary bands were seen with the exception of those associated to the satellited arms. H33258 staining enhanced the similarity among the three karyotypes, indicating that most of the differences in C-banding patterns arose from C-bands which showed indifferent reaction to H33258 staining: in fact, besides the differences in the structure of the satellited chromosomes, the H33258 stained metaphases of the three species were virtually indistinguishable.

\section{Discussion}

Although cytophotometric determination of nuclear DNA content using the Feulgen method may be subject to some reservation (Greilhuber 1986, 1988), we have chosen 30 min hydrolysis in $5 \mathrm{~N} \mathrm{HCl}$ at room temperature after a study of hydrolysis curve. Since nuclei were analysed in the same early prophase conditions from tissues at the same stage of development (we used the meristematic portion from $1 \mathrm{~cm}$ long secondary roots), and all squashes were stained together (with $V$. narbonensis meristems used as an internal standard) the observed differences in Feulgen absorption values do reflect real differences in the DNA content.

The result of our cytophotometric analyses indicate values of nuclear DNA content that disagree with the report of Maxted et al. (1991b): the divergences are probably due to the different method. When the absorption curves are examined it appears evident that the curve of $V$. kalakhensis differentiates from those of $V$. narbonensis and $V$. eristalioides. On examination of the DNA amount and the nuclear surface (Table 1) it appears evident that this species has more DNA in a smaller nuclear volume, implying a more condensed state of all chromatin and not merely a higher amount of heterochromatin.

As far as karyotype measurements are concerned, the automated image analysis system ensured a high degree of accuracy since the measurements were taken directly in the first image of the chromosomes as projected by the objective. In traditional chromosome measurement methods such as photography, serial treatments are applied to the image, tending to accumulate error in the final determination. The availability of such precise measurement methods allowed the exact determination of karyomorphological indices: the latter are considered to be directly correlated with the evolution of the karyotype as reports on Cicer (Ocampo et al. 1992) or on Vigna (Pignone et al. 1995b) can demonstrate.

The three species showed very similar karyotypes. The results obtained on V. narbonensis confirm previous reports (Perrino and Pignone 1981, Singh and Lelley 1982) and for V. kalakhensis and $V$. eristalioides this is the first report on karyomorphological parameters. Schafer (1973) hypothesised that all karyotypes present in the $V$. norbonensis complex could be derive from an ancestral species by a single translocation. DNA restriction endonucleases fragment analysis was used to obtain information on the genome organization of rDNA in the genus Vicia (Raina and Ogihara 1995). The taxa within the Narbonensis complex were observed to have fairly similar rDNA monomer size and restriction maps befit a common ancestry.

The cytological data gathered through chromosome banding do not support this hypothesis. At least for $V$. kalakhensis and $V$. eristalioides, a more complicated mechanism needs to be claimed, also to account for the observed variation in nuclear DNA content. The disagreement may probably be due to the fact that the general structure of rDNA regions is fairly well conserved in these species, on the other hand, these regions account for a limited amount of the genome. Conversely the cytophotometric and the chromosome banding methods target a vaster proportion of the genomic DNA. 
It is interesting to point out that the two approaches, karyomorphometry and cytophotometry, led to similar conclusions. The results of molecular analysis (Raina and Oghihara 1995) do not support diversity in the Narbonensis complex even if the authors have not analysed $V$. eristalioides. On the contrary the results obtained by studying the FokI elements in the genomes of $V$. faba and other Vicia species (Maggini et al. 1995), using biochemical approaches, support diversity in the Narbonensis complex. DNA sequences related to the FokI elements are not detectable even in species $(V$. galilea, $V$. hyaenisciamus, $V$. johannis) that belongs to the Narbonensis complex and are represented to a minimum extent in $V$. narbonensis.

It appears evident that in the examined species two classes of heterochromatin are present. The former reacts positively to both C-banding and fluochrome staining and is distributed on the telomeres, the latter is only evidenced by C-banding and is mostly intercalary. It is worth noting that the former class appears less affected by evolutionary changes than the latter. This may be the consequence of a different structural organisation of the two types of heterochromatin and may reflect also differences in the sequences hosted at those sites. A similar observation was made in Dasypyrum villosum (Cremonini et al. 1994, Pignone et al. 1995). The higher evolutionary stability of the heterochromatin class might explain the observation of Perrino and Pignone (1981) who reported limited variation for H33258 staining among the other species of the V. narbonensis complex.

One aspect still needs clarification: $V$. kalakhensis shows the highest level of heterochromatin as cytophotometrically determined in interphase nuclei and the lowest heterochromatin content in metaphase chromosomes. It needs to be stressed that the two methods estimate different levels of organization and two different functional stages. Differences in the nuclear heterochromatin might reflect different levels of genomic expression ( $V$. kalakhensis has the largest genome) while chromosomal heterochromatin reflects a mode of chromosome packaging. It is possible to hypothesize that V. kalakhensis possesses a higher level of interspersed sequences which altogether account for denser nuclei, but features the same level of sequences in heterochromatin localization.

\section{Acknowledgements}

The authors are indebted to the International Plant Genetic Resources Institute, Rome, Italy, for support to this research awarding a one-year training grant to Ms. Ngu at the IdG. The present research was part of the training programme of Mr. Tota who was awarded a grant from National Research Council of Italy (CNR, Roma). Moreover, a special thank is given to Dr. I. Galasso (IdG), for her constant attention and support in instructing both trainees. The research was partially supported by grants from M.U.R.S.T. (Roma) and from National Research Council of Italy (CNR, Roma).

\section{References}

Alkin, D. J., Goydir, D. J., Bisby, F. A. and While, R. J. 1986. Names and synonyms of species and subspecies of the Viciae. Issue 3, Vicieae Database Projet, Publication No. 7.

Bassi, P., Cionini, P. G., Cremonini, R. and Sassoli, O. 1984. Under-representation of nuclear DNA sequences in differentiating root cells of Vicia faba. Protoplasma 123: 70-77.

Berlyn, G. P., Dhillon, S. S. and Miksche, J. P. 1979. Feulgen cytophotometry of pine nuclei. II. Effect of pectinase in cell separation. Stain Technol. 540: 201-204.

Chooi, W. Y. 1971. Variation in nuclear DNA content in the genus Vicia. Genetics 68: 195-211.

Cremonini, R. 1990. Variability of nuclear DNA during plant development. In: Fifth International Yuoth Scool-Conference on Genetics. Albena, 11-15 September 1990, Bulgary, pp. 33-50.

Cremonini, R., Colonna, N., Stefani, A., Galasso, I. and Pignone, D. 1994. Nuclear DNA content, chromatin organization and chromosome banding in brown and yellow seed of Dasypyrum villosum (L.) P. Candargy. Heredity 72: 365-373. 
—, Funari, S. and Mazzuca, S. 1992. Cytology of Vicia species. I. Nuclear structure, karyological analysis and DNA content. Chromatin 1: 135-146.

—, Pignone, D., Funari, S. and Galasso, I. 1993. Cytology of Vicia species. II. Banding pattern and chromatin organization in Vicia atropurpurea Desf. Heredity 70: 628-633.

Di Terlizzi, P., Frediani, M., Cremonini, R. and Pignone, D. 1993. Chy-banding pattern and chromatin organization in Aegilops and Triticum species (Poaceae). Pl. Syst. Evol. 184: 1-10.

Frediani, M., Sassoli, O. and Cremonini, R. 1992. Nuclear DNA characterization of two species of Vicia: V. bythinica L. and V. narbonensis L. Biol. Plantarum 34: 335-344.

Giraldez, R., Cermeno, M. C. and Orellana, J. 1979. Comparison of the C-banding pattern in the chromosomes of inbred lines and open pollinated varieties of rye. Z. Pflanzenzuchtung 83: 40-48.

Greihuber, J. 1986. Severely distorted Feulgen-DNA amounts in Pinus (Coniferophytina) after nonadditive fixations as a result of meristematic self-tanning with vacuole contents. Can. J. Genet. Cytol. 28: 409-415.

- 1988. Self-tanning a new and important source of steichiometric error in cytophotometric determination of nuclear DNA content. P1. Syst. Evol. 158: 87-96.

— and Speta, F. 1976. C-banded karyotypes in the Scilla hohenackeri Group, S. persica and Puschkinia (Liliaceae). Plant Syst. Evol. 126: 149-188.

Hanelt, P. and Mettin, D. 1989. Biosystematics of the genus Vicia L. (Leguminosae). Ann. Rev. Ecol. Syst. 20: 199-223.

Huziwara, Y. 1962. Karyotype analysis in some genera of Compositae. VIII Further studies on the chromosomes of Aster: Am. J. Bot. 49: 116-119.

Khattab, A., Maxted, N. and Bisby, F. A. 1988. Close relatives of the fiba bean from Syria: a new species of Vicia and notes on V. hyaeniscyanus (Leguminosae). Kew Bulletin 43: 535-540.

Kupicha, F. K. 1976. The infragenic structure of Vicia. Notes Royal Botan. Garden Edinburg 34: 287-326.

Levan, A., Freda, K. and Sandberg, A. A. 1964. Nomenclature for centromeric position on chromosomes. Hereditas 52: 201-220.

Maggini, F., D'ovidio, R., Gelati, M. T., Frediani, M., Cremonini, R., Ceccarelli, M., Minelli, S. and Cionini, P. G. 1995. The FokI DNA repeats in the genome of Vicia faba: species-specificity, structure, redundancy modulation, nuclear organization. Genome 38: 1255-1261.

Maxted, N. 1988. A new Vicia from Southern Turkey. Note Royal Botanic. Garden Edinburg 45: 453-456.

-, Callimassa, M. A. and Bennett, M. D. 1991a. Cytotaxonomic studies of Eastern Mediterranean Vicia species (Leguminosae). Pl. Syst. Evol. 177: 221-234.

- Khattab, A. and Bisby, F. A. 1991b. The newly discovered relatives of Vicia faba L. do little to resolve the enigma of its origin. Bot. Chron. 10: 435-465.

Ocampo, B., Venora, G., Errico, A., Singh, K. B. and Saccardo, F. 1992. Karyotype analysis in the genus Cicer. J. Genet. Breed. 46: 229-240.

Perrino, P. and Pignone, D. 1981. Contribution to the taxonomy of Vicia species belonging to the section Faba. Kulturpflanze 39: 311-319.

Pignone, D., Galasso, I., Rossino, I. and Mezzanotte, R. 1995a. Characterization of Dasypyrum villosum (L.) Candargy chromosomal chromatin by mens of in situ restriction endonucleases, fluorochromosomes, silver staining and Cbanding. Chromosome Research 3: 109-114.

- - - and Venora, G. 1995b. Karyomorphological and heterochromatin similarities among four Vigna species. Genet. Res. Crop Evol. 42: 56-60.

Raina, S. N. and Ogihara, Y. 1995. Ribosomal DNA repeat unit polymorphism in 49 Vicia species. Theor. Appl. Genet. 90: $477-486$.

Schafer, H. I. 1973. Zur taxonomic der Vicia narbonensis gruppe. Kulturpflanze 21: 211-273.

Scott, A. J. and Knott, M. 1974. A cluster method for grouping means in the analysis of variance. Biometrics 30: 505-512.

Singh, V. P. and Lelley, T. 1982. Giemsa C-banding karyotype of Vicia narbonensis as compared to Vicia faba. FABIS Newlett. 4: 24-25.

Stebbins, L. 1971. Chromosomal evolution in higher plants. Edward Arnold Ltd., London, UK.

Venora, G., Conicella, C., Errico, A. and Saccardo, F. 1991. Karyotyping in plants by an image analysis system. J. Genet. Breed. 45: 233-240.

—, Galasso, I. and Pignone, D. 1995. Quantitative heterochromatin determination by means of image analysis. J. Genet. Breed. 48: 187-190. 